\title{
Invalidi in dostopnost: kako uspešni smo v Sloveniji pri odstranjevanju in preprečevanju grajenih in komunikacijskih ovir?
}

Decembra 2008 je bila končana raziskava, z naslovom Ukrepi za uresničevanje pravic invalidov do dostopa brez ovir, ki sta jo izvedla Urbanistični inštitut Republike Slovenije in Inštitut Republike Slovenije za socialno varstvo. Raziskavo sta sofinancirala Javna agencija za raziskovalno dejavnost Republike Slovenije in Ministrstvo za delo, družino in socialne zadeve Republike Slovenije. Glavni namen raziskave je bila izvedba obsežne analize stanja invalidskega varstva $\mathbf{v}$ Sloveniji, analizirati dostopnost grajenega okolja, komunikacij in informacij ter ugotoviti, kako se izvajajo ukrepi, ki so bili na državni ravni sprejeti za zagotavljanje invalidom prostega gibanja in socialnega vključevanja. Osrednji del raziskave tvorita obsežni anketi, in sicer anketa invalidov posameznikov in anketa predstavnikov najpomembnejših invalidskih organizacij v Sloveniji. Glavna hipoteza pri izvajanju raziskave je bila, da je bilo do sedaj premalo narejenega za uresničevanje pravic inva- lidov, opredeljenih v različnih dokumentih. Hipotezo smo oblikovali na podlagi pregleda obstoječe literature ter zakonodaje in politik povezanih $\mathrm{z}$ invalidi. Rezultati empirične raziskave povsem potrjujejo pravilnost vodilne hipoteze. $\mathrm{V}$ prispevku predstavljamo rezultate obeh anket, povzemamo ključne ugotovitve, na koncu pa podajamo nekaj predlogov ukrepov za učinkovitejše uresničevanje pravic invalidov do dostopa brez ovir.

Ključne besede: invalidi, grajene ovire, komunikacijske ovire, gibanje brez ovir, dostopnost, preprečevanje in odstranjevanje ovir 


\section{Uvod}

Vprašanje invalidnosti je že nekaj časa priznano kot pomembno politično vprašanje $\mathrm{v}$ povezavi $\mathrm{z}$ zagotavljanjem univerzalnih človekovih pravic. Ocenjuje se, da funkcionalno ovirani ljudje sestavljajo 15-20 \% aktivnega prebivalstva Evrope. Po podatkih o številu invalidov glede na pravno definiran status iz leta 2002 pa je bilo tedaj v Sloveniji nekaj manj kot 170.000 invalidov. $\mathrm{V}$ primerjavi $\mathrm{s}$ številom takratnega prebivalstva $\mathrm{v}$ Sloveniji so torej invalidi s statusom pomenili 8,48 \% celotne populacije (Vertot, 2007). Kljub njihovi relativni številčnosti pa so invalidi žal pogosto izpostavljeni različnim oblikam diskriminacije. Najprej gre za ovire v grajenem okolju, ovire glede dostopnosti informacij in ovire glede dostopnosti komunikacij. Uresničevanje pravic invalidov in omogočanje njihove polne aktivne udeležbe $\mathrm{v}$ družbi je tako za vse države velik izziv.

Tako kot velja za vsa druga področja, morajo politični ukrepi za reševanje problemov funkcionalno oviranih ljudi v grajenem okolju temeljiti na analizah družbenih stanj v določenem času in prostoru. Zaradi naraščajoče zavesti o tej problematiki lahko ugotovimo, da se v zadnjem času s to temo ukvarja vse več raziskovalcev in drugih strokovnjakov. Pod to temo se v literaturi pojavijo različne podteme. Nekateri avtorji so se osredotočili na probleme, ki so povezani z načrtovanjem objektov in oblikovanjem grajenega okolja (na primer Balchin in Rhoden, 1998; McGrail idr., 2001; Burns, 2004; Harrison, 2004; Bulos in Teymur, 1993; Thomas, 2004; Imrie, 2004a; Ellison in Burrows, 2007). Kljub različnim pristopom posameznih avtorjev pri teh razpravah velja splošna ugotovitev, da je pri načrtovanju grajenega okolja nujno treba upoštevati vse predpise in gradbene standarde, ki so namenjeni zagotavljanju invalidom neoviranega dostopa. Gre za t. i. »vključujoče oblikovanje « (ang. inclusive design) ali »oblikovanje za vse« (ang. design for all) (Kervina idr., 2007) oziroma » univerzalno načrtovanje « (ang. universal design) (Sandhu idr., 2001; internet 1). Pri tem velja posebej omeniti, na primer, koncept $\gg$ domov za vse življenje « (ang. life-time homes) (Milner in Madigan, 2004; Barlow in Venables, 2004, internet 2). Pri tem konceptu gre za bivanjske prostore, ki omogočajo funkcionalno prilagoditev potrebam uporabnika skozi vse življenje, pri čemer so stroški prilagoditve minimalni.

Na drugi strani pa Harrison in Davis (2001) opozarjata na nevarnost prostorske izključitve, ki je posledica sodobnih pristopov $\mathrm{k}$ načrtovanju posebnih bivališč za invalide. Pri tem pri prostorskem načrtovanju izpostavljata uporabo pojma » posebne potrebe invalidov «, ki lahko pripelje do segregacije določenih skupin zaradi strogih posebnih urbanistično-arhitektonskih oblikovalskih zahtev. Avtorja trdita, da lahko takšni pristopi vodijo $\mathrm{k}$ ustvarjanju »invalidskih getov«. Kot boljše rešitve predlagata pristope, kot so na primer » podporne življenjske mreže « (ang. living support networks), » okoli vogala « (ang. round the corner) oziroma »sobivanje « (ang. life-sharing). Skupna značilnost vseh teh pristopov je, da invalidnim osebam nudijo podporo, $s$ tem da tisti, ki daje podporo, živi v bližini, »za vogalom «. Glavna misel teh pristopov je, da omogočajo skoraj popolno neodvisnost sicer gibalno oviranih ljudi.

Drugi avtorji obravnavajo tehnološke in tehnične inovacije, ki so namenjene olajšanju življenja in izboljšanju kakovosti bivanja invalidov (na primer Peace in Holland, 2001; Brenton, 2001; Imrie, 2004b; Hanson, 2001; Fisk, 2001; Heywood, 2004; Kelly, 2001; Drewsbury idr., 2004). V tem primeru gre predvsem za proučevanje in predstavitev novih načinov za zagotavljanje invalidom čim bolǰ̌e možnost za samostojno bivanje v izbranem stanovanju s pomočjo tehnoloških rešitev. Pomembna inovacija na tem področju je vsekakor »pametna hiša « (ang. smart house) (Pecora in Cesta, 2007; Zupan idr., 2007). Pametne hiše so opremljene $z$ najsodobnejšo opremo, $s$ pripomočki in tehnologijo, ki so med seboj funkcionalno povezani, s čimer so zagotovljeni pogoji, da imajo lahko invalidi najvišjo stopnjo funkcionalne samostojnosti in neodvisnosti. Po Ostrovršniku (2004) so osnovne lastnosti pametne hiše funkcionalnost, fleksibilnost, varnost, varčevanje z energijo, udobje, višja kakovost bivanja in predvsem čim širša dostopnost, kar omogoča neodvisnost in samostojno življenje. Poleg pametne hiše obstaja več drugih tehnoloških rešitev na tem področju, ki so $\mathrm{v}$ literaturi pogosto predstavljene $\mathrm{z}$ izrazom »podporne tehnologije « (ang. assistive technologies). »Podporna tehnologija je splošni izraz za katero koli napravo ali sistem, ki omogoča posamezniku, da opravi svojo nalogo, ki bi je sicer ne bi mogel narediti, ali pa povečuje preprostost in varnosti, s katero se lahko določena naloga izvede « (Cowan idr., 1999; navedeno v: Dewsbury idr., 2004: 811). Podrobnejša predstavitev nekaterih pomembnejših podpornih tehnologij je $\mathrm{v}$ končnem poročilu raziskave o uresničevanju pravic invalidov (Sendi idr., 2008).

Tudi pri nas je v zadnjem času mogoče opaziti težnjo po naraščanju števila raziskav ter znanstvenih in strokovnih objav na tem področju. Publikacija, ki jo je uredila B. Kresal (2007) izčrpno predstavlja pravice invalidov na področjih izobraževanja, zaposlovanja in dela, zdravstvenega varstva in zavarovanja, pokojninskega in invalidskega zavarovanja, starševskega varstva in družinskih prejemkov, socialnega varstva, davčnih olajšav, vojnih invalidov, invalidskih organizacij ter uveljavljanja in varstva pravic.

S. Kukova idr. (2005) obravnavajo pravice oseb z intelektualnimi ovirami, ki jih opredeljujejo kot najbolj diskriminirano kategorijo invalidov. Pravice intelektualno oviranih oseb obravnavajo predvsem z vidika dostopnosti do izobraževanja in zaposlovanja. Diskriminacija zaradi nedostopno grajenega okolja 
je bila prav tako tema doktorske disertacije V. Vodeb (2007), $\mathrm{v}$ kateri se je avtorica osredotočila na diskriminacijo invalidov (predvsem invalidov s fizičnimi motnjami) pri dostopnosti do bivalnega okolja in javnih prostorov.

Osrednje vlogo na področju raziskovanja problematike invalidske oskrbe v Sloveniji ima vsekakor Inštitut Republike Slovenije za socialno varstvo (v nadaljevanju: IRSSV). Med pomembnejšimi raziskavami, ki so bile izvedene na omenjenem inštitutu, velja omeniti študiji avtoric M. Nagode in P. Dremelj (2004, 2005), v okviru katerih so bile opravljene obsežne analize omrežij socialne podpore za ljudi z gibalnimi težavami v Sloveniji. B. Kobal idr. (2006) pa v študiji o socialnih transferjih za invalide obravnavajo problematiko financiranja invalidske oskrbe v Sloveniji. Na enako temo so za potrebe priprave zakona o izenačevanju možnosti invalidov raziskovalci IRSSV izvedli analizo socialno ekonomskega položaja invalidov (Kobal idr., 2007). Pomembna raziskava na tem področju je bila primerjalna analiza neodvisnega življenja invalidov v izbranih državah Evropske unije (Kobal idr., 2004). Namen študije je bil analizirati pojmovanja neodvisnega življenja invalidov in $s$ tem povezane ureditve osebne asistence na Švedskem, v Veliki Britaniji, Nemčiji, Franciji, na Nizozemskem in Slovaškem ter predstaviti možnosti za uvajanje osebne asistence tudi v slovenskem prostoru.

\subsection{Pomembnejši mednarodni dokumenti, ki se nanašajo na pravice invalidov}

$\mathrm{Na}$ svetovi ravni je leto 1993 prelomnica glede aktivnosti za izboljšanje dostopnosti in uresničevanje pravic invalidov. $\mathrm{V}$ tem letu je generalna skupščina Združenih narodov prvič sprejela standardna pravila za izenačevanje možnosti invalidov. Drugi ključni mejnik na tem področju je vsekakor leto 2001, v katerem je generalna skupščina Združenih narodov sprejela priporočila komisije za človekove pravice in komisije za socialni razvoj, da se pripravi konvencija za pravice invalidov. Ta zgodovinski dokument, ki je bil sprejet decembra 2006, je prvi pravno zavezujoči dokument Združenih narodov na področju invalidskega varstva. Njegov temeljni namen je zagotoviti uveljavljanje človekovih pravic oziroma načela enakih možnosti in enake obravnave ter preprečevanja diskriminacije, ki jo doživljajo invalidi na različnih področjih življenja. Konvencija priznava pomen dostopnosti fizičnega, socialnega, ekonomskega okolja ter dostopnosti informacijskih in komunikacijkih tehnologij pri omogočanju invalidov, da polnopravno uživajo človekove pravice in osnovne svoboščine.

Na območju Evropske unije je na tem področju prav tako pomembna Amsterdamska pogodba, s katero je Evropska skupnost ( $v$ 13. členu) sprejela spoštovanje človekovih pravic in temeljnih načel kot temeljno načelo za obravnavanje in razre- ševanje problemov invalidov. Konkretno gre v tem primeru za zagotavljanje enakopravne življenjske možnosti za funkcionalno ovirane ljudi. Omenjena pogodba zavezuje države članice $\mathrm{k}$ izvajanju dolgoletne strategije za boj proti diskriminaciji, razvijanju socialne integracije in aktivne udeležbe, povečanju izobraževanja, usposabljanja, vseživljenjskega učenja, zaposlitvenih možnosti, omogočanju samostojnega življenja ter povečanju ponudbe in kakovosti oskrbe ter pomožnih tehnologij (internet 3).

Za izvajanje omenjene strategije je leta 2000 Evropska komisija sprejela direktivo Sveta o vzpostavitvi splošnega okvira za enako obravnavanje pri zaposlitvi in poklicih. Ta pravno zavezujoči dokument prepoveduje vsakršno diskriminacijo, še zlasti izrecno prepoveduje diskriminacijo zaradi invalidnosti (internet 4). Pomemben dokument Evropske komisije na tem področju je tudi Evropski akcijski načrrt 2004-2010: Enake možnosti za invalidne osebe.

\subsection{Invalidsko varstvo v Sloveniji}

V Sloveniji so pravice invalidov (tako kot za vse ostale državljane) sicer zagotovljene s 14. členom ustave, po katerem so v Sloveniji »vsakomur zagotovljene enake človekove pravice in temeljne svoboščine, ne glede na narodnost, raso, spol, jezik, vero, politično ali drugo prepričanje, gmotno stanje, rojstvo, izobrazbo, družbeni položaj, invalidnost ali katero koli drugo osebno okoliščino, vsi pa so enaki tudi pred zakonom « (Ustavni zakon o spremembi 14. člena Ustave Republike Slovenije, Ur. l. RS, št. 69/2004: 8461).

Na podlagi raznih dokumentov Evropske skupnosti (zlasti Amsterdamske pogodbe in Evropskega akcijskega načrta) je Slovenija sprejela pomembna dokumenta na tem področju, in sicer: Nacionalne usmeritve za izboljšanje dostopnosti grajenega okolja, informacij in komunikacij za invalide - Strategija Dostopna Slovenija in Akcijski program za invalide 20072013. Vsebina obeh dokumentov ter tudi politike in ukrepi, ki se nanašajo na pravice invalidov v Sloveniji, so podrobneje predstavljeni v končnem poročilu raziskave (Sendi idr., 2008). $\mathrm{V}$ pripravi pa sta še dva pomembna zakona, in sicer: zakon o izenačevanju možnosti invalidov ter zakon o dolgotrajni oskrbi in zavarovanju za dolgotrajno oskrbo.

Strategija Dostopna Slovenija in Akcijski program za invalide 2007-2013 sta bila glavno izhodišče za omenjeno raziskavo, ki je osnova za ta prispevek. Strategija temelji na uresničevanju drugega poglavja Ustave Republike Slovenije, v katerem se govori o človekovih pravicah in temeljnih svoboščinah, $v$ njem pa je v 14. členu določena tudi enakost pred zakonom. Cilji, ki so določeni v strategiji, temeljijo na ugotovitvi, da je invalidsko varstvo ena najobčutljivejših in najbolj specifičnih 
sestavin splošne družbeno-razvojne, zlasti ekonomske politike. $\mathrm{V}$ strategiji je zapisano, da naj bi se vsi našteti ukrepi uresničili najkasneje do leta 2025. Prvi ukrepi naj bi se uresničili že konec leta 2006 in leta 2007 (prilagoditev taksivozil, zagotovitev prevoza $\mathrm{v}$ javnem potniškem prometu za psa vodnika slepega invalida in podobno).

Akcijski program za invalide 2007-2013 pa podrobno določa naloge politike invalidskega varstva med letoma 2007 in 2013, konkretne cilje, ki je treba uresničevati na posameznih področjih in glavne nosilce, ki so zadolženi za njihovega uresničevanja. Cilji akcijskega programa so (Ministrstvo za delo, družino in socialne zadeve, 2006):

- V družbi povečati osveščenost o invalidih, njihovem prispevku $\mathrm{k}$ razvoju družbe, pravicah, dostojanstvu in potrebah.

- Vsi invalidi imajo pravico, da enakovredno in brez diskriminacije izbirajo, kje in kako bodo živeli, ter so polno vključeni v življenje skupnosti in sodelujejo v njem.

- Invalidom zagotavljati dostopnost grajenega okolja, prevoza, informacij in komunikacij.

- Na podlagi enakih možnosti in brez diskriminacije zagotavljati vključujoč izobraževalni sistem na vseh ravneh in vseživljenjsko učenje.

- Invalidom zagotavljati dostop do dela in zaposlitve brez diskriminacije v delovnem okolju, ki je invalidom odprto in dostopno ter jih vključuje.

- Invalidom zagotavljati ustrezno življenjsko raven, finančno pomoč in socialno varnost.

- Invalidom zagotavljati učinkovito skrb za njihovo zdravje.

- Invalidom zagotavljati vključenost $\mathrm{v}$ kulturne dejavnost in sodelovanje na področju dostopnosti do kulturnih dobrin na enakopravni osnovi.

- Invalidom zagotavljati sodelovanje pri športnih in rekreativnih dejavnostih.

- Invalidom zagotavljati enakopravno udeležbo v verskem in duhovnem življenju v njihovih skupnostih.

- Krepitev delovanja invalidskih organizacij ter

- odkrivanje in preprečevanje nasilja ter diskriminacije nad invalidi.

Čeprav so v obeh dokumentih zelo natančno opredeljeni cilji in številni ukrepi za njihovo uresničevanje, smo v raziskavi izhajali iz domneve, da za uspešno izvedbo navedenih ciljev v tem času ni bilo veliko narejenega. Vodilna hipoteza pri raziskavi je bila, da je za neučinkovito izvajanje ukrepov najbolj krivo nedosledno oziroma nezadostno upoštevanje ali sploh neupoštevanje zakonov in drugih predpisov, ki se nanašajo na pravice invalidov.

Osnovni namen raziskave je torej bil ugotoviti, kateri dodatni ukrepi so nujno potrebni za učinkovitejšo realizacijo pravice invalidov do gibanja brez ovir. Glavni cilji raziskave pa so bili (Sendi idr., 2008):

- Ugotoviti, katere so glavne ovire, $s$ katerimi se invalidi srečujejo pri uresničevanju pravic do dostopa brez ovir.

- Na podlagi analiz politik in ukrepov Evropske unije in Slovenije ter mednarodnih dokumentov na področju dostopnosti grajenega okolja, komunikacij in informacij ter na podlagi pregleda najnovejših pristopov $\mathrm{k}$ odpravljanju ovir, povezanih z dostopnostjo grajenega okolja, komunikacij in informacij, predstaviti in širiti informacije o primerih dobrih praks.

- Nosilcem odločanja pripraviti ustrezne metodologije in orodja za učinkovitejše reševanje problemov dostopa brez ovir.

Raziskava je bila izvedena v štirih glavnih delih (prav tam):

- pregled politik in ukrepov Evropske unije in Slovenije na področju dostopnosti grajenega okolja, komunikacij in informacij;

- pregled najnovejših pristopov $k$ odpravljanju ovir, povezanih z dostopnostjo grajenega okolja, komunikacij in informacij;

- empirična raziskava - obsežna anketa med invalidi posamezniki in invalidskimi organizacijami ter

- oblikovanje predlogov ukrepov za uresničevanje pravic invalidov do dostopa brez ovir.

V tem prispevku predstavljamo rezultate empirične raziskave, navedenih pa je tudi nekaj predlogov ukrepov za uresničevanje pravic invalidov do dostopa brez ovir.

\section{Empirična raziskava}

\subsection{Metodologija empirične raziskave}

Najpomembnejši del raziskave sta obsežni anketi, ki smo ju izvedli med invalidi posamezniki in invalidskimi organizacijami. $\mathrm{Za} \mathrm{izvedbo} \mathrm{anket} \mathrm{smo} \mathrm{pripravili} \mathrm{dva} \mathrm{anketna} \mathrm{vprašalnika,} \mathrm{in}$ sicer enega za invalide posameznike in drugega za predstavnike invalidskih organizacij. Namen anketiranja je bil ugotoviti, katere so konkretne ovire grajenega okolja in komunikacijske ovire na območju Slovenije, s katerimi se funkcionalno ovirani ljudje srečujejo pri uresničevanju svojih pravic v vsakdanjem življenju.

Ovire grajenega okolja smo opredelili kot tiste, ki zajemajo arhitektonske in tehnološke ovire (klančine, stopnice, cestni robniki in podobno) ter se torej nanašajo na načrtovanje in gradnjo javnih in zasebnih zgradb ter načrtovanje, razvoj in vzdrževanje javnih in zasebnih površin. 
Komunikacijske ovire pa smo opredelili kot tiste, ki zajemajo neobstoj tolmačev, taktilnih informacij, indukcijskih zank, podnapisov, računalnikov in spleta, govornih najav, prikazovalnikov in podobno. Ti se nanašajo na sisteme za prenos in izmenjavo informacij ter na sisteme za izvajanje množičnega komuniciranja (prek radia, televizije, časopisov, interneta).

Vprašanja za invalide posameznike smo razdelili v osem sklopov, in sicer na uvodna vprašanja, ovire v potniškem prometu, ovire na področju izobraževanja, usposabljanja in zaposlovanja, ovire na področju izvajanja dejavnosti zdravstvenega in socialnega varstva, ovire pri dostopu do storitev državne uprave, ovire pri dostopu do ponudbe kulturnih ustanov, ovire pri aktivnostih preživljanja prostega časa (šport, rekreacija, turizem) ter demografske in socio-ekonomske podatke. Anketni vprašalnik za organizacije je bil po vsebini zelo podoben. Razlikoval se je le v tem, da se prvi sklop vprašanj v vprašalniku za posameznike nanaša na opravljanje posameznih aktivnosti in pripomočke, $s$ katerimi si invalidi pri teh aktivnostih pomagajo, pri organizacijah pa na podatke o organizaciji (organiziranost, članstvo, financiranje, dejavnosti, sodelovanje s člani). Vprašalnik za organizacije tudi ni vseboval sklopa o demografskih in socioekonomskih podatkih.

Glede na to, da na državni ravni ne obstajajo javno dostopne evidence o invalidih in vrstah invalidnosti, smo se po pomoč za izvedbo anketiranja med invalidnimi osebami (vprašalnik za invalide) obrnili na Nacionalni svet invalidskih organizacij Slovenije (v nadaljevanju: NSIOS) in v nadaljevanju na posamezne invalidske organizacije, ki so se na našo prošnjo pozitivno odzvale, nam omogočile dostop do svojih članov in zaradi varovanja osebnih podatkov opravile tudi del postopka anketiranja. Med delujočimi 26-imi invalidskimi organizacijami na državni ravni (vir zanje je bil izpis iz registra invalidskih organizacij (v nadaljevanju: OI) na državni ravni, posredovan s strani ministrstva za delo, družino in socialne zadeve) smo izbrali 10 invalidskih organizacij, ki so po svojem delovanju in članih reprezentativne glede na obravnavano problematiko (ovire grajenega okolja in komunikacijske ovire):

- Društvo distrofikov Slovenije,

- Zveza društev slepih in slabovidnih Slovenije,

- Društvo larigektomiranih Slovenije,

- Zveza društev gluhih in naglušnih Slovenije,

- Združenje multiple skleroze Slovenije,

- Društvo paralitikov Slovenije PARAS,

- Zveza paraplegikov Slovenije,

- Sonček Zveza društev za cerebralno paralizo Slovenije,

- Zveza Sožitje zveza društev za pomoč osebam z motnjami v duševnem razvoju Slovenije,

- Društvo VITA za pomoč po nezgodni poškodbi glave.
Anketiranje je bilo izvedeno v dveh fazah, in sicer najprej za invalide posameznike in nato za invalidske organizacije. $\mathrm{Za}$ prvo anketiranje smo reprezentativne invalidske organizacije prosili, naj vprašalnike posredujejo svojim članom tako, da so iz evidenc, ki jih vodijo o svojih članih in glede na raziskovalni vzorčni okvir, naključno izbrali približno polovico članov iz urbanega (mestnega) okolja in polovico iz podeželskega okolja. Če je posamezna organizacija združevala več podružnic oziroma občinskih društev, so vprašalnike enakomerno razposlali vsem njihovim podružnicam. Vzorčni okvir smo pripravili glede na velikost organizacij in reprezentativno zastopanost invalidov s posameznimi vrstami invalidnosti. Skupno smo razposlali 800 vprašalnikov za invalide posameznike.

Vprašalnik za invalidske organizacije, s katerim smo predstavnike (večinoma predsednike) organizacij spraševali o ovirah grajenega in komunikacijskega okolja, s katerimi se srečujejo njihovi člani, smo poslali 116 organizacijah (pri tem se nismo obračali na krovne organizacije, temveč na njihova posamezna društva) po vsej Sloveniji. Vsaki organizaciji smo torej poslali po en vprašalnik, ki ga je praviloma izpolnil predsednik.

\subsection{Rezultati empirične raziskave}

\subsubsection{Zbiranje podatkov in odzivnost}

Ker smo od invalidov posameznikov do predvidenega roka ( 15 . maj 2008) dobili vrnjenih zelo malo izpolnjenih vprašalnikov za invalide, smo poklicali vsa omenjena društva ter se z njimi pogovorili o težavah in vzrokih za slab odziv. Predstavnike organizacije smo prosili, naj svojim članom, če ti potrebujejo pomoč pri izpolnjevanju ankete, pomagajo. Ob koncu maja (27. maja 2008) smo se oglasili pri Društvu distrofikov Slovenije ter Zvezi društev slepih in slabovidnih Slovenije, invalide, ki so prejeli anketo, pa smo k sodelovanju povabili tudi telefonsko. V začetku junija 2008 smo invalidskim organizacijam še enkrat poslali dopis, v katerem smo jih prosili, naj svoje člane še enkrat povabijo k sodelovanju.

Ob koncu anketiranja je vprašalnike za invalide vrnilo 181 invalidov posameznikov, kar je 22,6 \% poslanih anketnih vprašalnikov. Najvišjo stopnjo odzivnosti je dosegla Zveza društev gluhih in naglušnih (46\%), ki je v procesu anketiranja intenzivno sodelovala, saj je svoje člane spodbujala in jim pomagala pri izpolnjevanju vprašalnika. Gluhe osebe so imele pri izpolnjevanju vprašalnika veliko težav, saj je vprašalnik obsežen in zapleten, zato je bila pomoč predstavnikov organizacij pri razumevanju vprašalnika nadvse koristna. Podobno stopnjo odzivnosti je dosegla tudi Zveza paraplegikov (42\%), največ $\mathrm{v}$ celoti izpolnjenih vprašalnikov smo dobili prav od njihovih članov, kar je slaba četrtina vseh vrnjenih vprašalnikov. Najnižja stopnja odzivnosti je bila dosežena pri članih Zveze Sonček $(10 \%)$ in Zveze Sožitje (11\%). 
Nekaj članov invalidskih organizacij, ki so prejeli našo anketo, se je odzvalo tudi po telefonu. Večina njihovih mnenj in odzivov se je nanašala na zapletenost in zahtevnost vprašalnika, veliko pa jih je imelo tudi pomisleke o koristnosti in smiselnosti takih anket, saj bi (po njihovem mnenju) veliko izboljšav prineslo že korektno izvajanje trenutno veljavnih predpisov na področju obravnavane tematike.

Ko smo končali anketiranje invalidov posameznikov, smo pričeli anketirati predstavnike organizacij. Konec junija 2008 smo izbranim organizacijam poleg vprašalnika za organizacije poslali še dopis izvajalcev raziskave, ki je vseboval obrazložitev cilja in namena raziskave, pismo podpore NSIOS-a in ovojnico z znamko. Vprašalnik je bil ves čas dostopen tudi v elektronski obliki na spletni strani. V avgustu in septembru smo tiste organizacije, ki niso vrnile izpolnjenega vprašalnika, poklicali in jih ponovno vljudno prosili za njihov odziv na povabilo $\mathrm{k}$ sodelovanju. Mnogi so sodelovanje zavrnili z obrazložitvijo, da take ankete ne prinašajo izboljšav za invalide, da so prezasedeni oziroma prezaposleni s pomembnejšimi zadevami in podobno, zato smo ob koncu septembra zbiranje podatkov končali.

Stopnja odzivnosti pri invalidskih organizacijah je bila nekoliko višja kot stopnja odzivnosti invalidov, saj je izpolnjene vprašalnike vrnilo 41 predstavnikov organizacij, ker je 35,3\%. Nekatera društva in zveze niso vrnili izpolnjenih vprašalnikov (Zveza Sonček, Društvo distrofikov in Društvo paralitikov Slovenije), iz česar sklepamo, da v raziskavi niso želeli sodelovati.

Visoko stopnjo odzivnosti je, tako kot pri anketiranju invalidov posameznikov, ponovno dosegla Zveza društev gluhih in naglušnih (75\%). Predstavniki organizacij in tudi invalidi sami si prizadevajo za ureditev razmer na tem področju (predvsem na področju komunikacijskih ovir), zato so bili zelo pripravljeni sodelovati pri raziskavi, kar je razvidno iz odzivnosti in iz pogostih pogovorov s predstavniki organizacij. Kot rečeno, je bila skupna odzivnost predstavnikov organizacij nekoliko višja kot odzivnost invalidov, čeprav ne moremo trditi, da je odzivnost velika.

Glede na aktualno problematiko lahko rečemo, da smo pričakovali večji odziv. Manjša odzivnost je najverjetneje posledica več dejstev:

- občutljivosti obravnavane problematike in bojazni anketirancev, da varovanje osebnih podatkov ne bo zagotovljeno;

- nezmožnosti samostojnega izpolnjevanja anketnega vprašalnika za nekatere kategorije invalidov (osebe z duševnimi motnjami, slepi);

- (že omenjena) ravnodušnost invalidov, predvsem pa predstavnikov organizacij, saj so bili pogosto pozvani $\mathrm{k}$ odgovarjanju na različne vprašalnike ter podajanju svojih mnenj in mogočih rešitev, čeprav se v praksi ukrepi in rešitve ne načrtujejo ne udejanjajo v dovolj velikem obsegu.

\subsubsection{Analiza rezultatov}

V nadaljevanju predstavljamo rezultate obeh anket. Za lažjo primerjavo med odgovori invalidov posameznikov in predstavnikov organizacij smo najpomembnejše rezultate po posameznih področjih združili ter predstavili v preglednicah kot deleže odgovorov invalidov posameznikov in predstavnikov organizacij glede srečevanja invalidov z veliko in zelo veliko ovirami grajenega in komunikacijskega okolja.

\section{Ovire v potniškem prometu}

Med vrste potniškega prometa smo uvrstili mestni potniški promet, medkrajevni potniški promet, prevoze $s$ taksiji, železniški promet, letalski promet in ladijski promet.

V splošnem je delež predstavnikov organizacij, ki menijo, da se invalidi v Sloveniji v potniškem prometu srečujejo z veliko in zelo veliko ovirami - v primerjavi z invalidi posamezniki - , višji in znaša za vsako od obeh oblik ovir več kot štiri desetine - za grajene ovire $41 \%$, za komunikacijske pa $46 \%$, medtem ko je tega mnenja manj kot tretjina invalidov posameznikov, in sicer $30 \%$ glede grajenih in $32 \%$ glede komunikacijskih ovir.

Po mnenju invalidov posameznikov in tudi predstavnikov organizacij sta z vidika grajenih ovir v Sloveniji najbolj problematična medkrajevni avtobusni promet in železniški promet (preglednica 1). Predstavniki organizacij ti vrsti potniškega prometa ocenjujejo tudi kot najbolj problematični z vidika komunikacijskih ovir, posamezniki pa menijo, da se invalidi z veliko in zelo veliko komunikacijskimi ovirami srečujejo tudi v letalskem prometu. Kot najugodnejši so se izkazali prevozi s taksijem, kar seveda ni presenetljivo, saj gre glede na ostale vrste prevozov za najbolj individualizirano obliko, kar pa prinaša tudi visoko ceno storitve.

Najpomembnejše ovire grajenega okolja in komunikacijske ovire na področju potniškega prometa

Pomembna grajena ovira na področju potniškega prometa so za invalide vhodi in izhodi iz stavb potniškega prometa oziroma vstopi in izstopi iz prevoznih sredstev. Ti po mnenju predstavnikov organizacij ne bi smeli imeti stopnic, previsokih razlik v ravni tal (robnikov), preozkih vrat in prehodov. Predstavniki izpostavljajo, da gre pri dostopnosti do prevoznih sredstev za dva ločena problema: eden je slaba dostopnost, v smislu tega, kako je postaja zgrajena, drugi je slaba dostopnost, 
Preglednica 1: Srečevanje invalidov z veliko in zelo veliko ovirami grajenega in komunikacijskega okolja pri dostopu do storitev potniškega prometa

\begin{tabular}{lllll}
\hline \multirow{2}{*}{ Vrsta potniškega prometa } & \multicolumn{2}{l}{ Grajene ovire (\%) } & \multicolumn{2}{l}{ Komunikacijske ovire (\%) } \\
\cline { 2 - 5 } & posamezniki & predstavniki organizacij & posamezniki & predstavniki organizacij \\
\hline mestni avtobusni promet & 30,0 & 48,0 & 30,0 & 45,0 \\
\hline medkrajevni avtobusni promet & 40,0 & 52,0 & 37,0 & 48,0 \\
\hline prevozi s taksiji & 18,0 & 26,0 & 24,0 & 44,0 \\
\hline železniški promet & 34,0 & 55,0 & 31,0 & 50,0 \\
\hline letalski promet & 27,0 & 25,0 & 37,0 & 45,0 \\
\hline ladijski promet & 27,0 & 32,0 & 35,0 & 42,0 \\
\hline
\end{tabular}

v smislu tega, da je postaja oddaljena. Predstavniki invalidskih organizacij in tudi invalidi posamezniki kot komunikacijsko oviro v potniškem prometu najpogosteje omenjajo problem zvočnih opozoril, prikazovalnikov in oznak. Anketirani invalidi izpostavljajo še različne težave pri komuniciranju in pridobivanju informacij o prevozih. V zvezi s tem predstavniki invalidov navajajo, da se informacije ne osvežujejo dovolj pogosto, da vozni redi niso dobro vidni (premajhen tisk, kar je problematično pri slabovidnih) in podobno.

Predlogi za zmanjševanje ovir grajenega okolja in komunikacijskih ovir na področju potniškega prometa

Predlogi anketirancev za zmanjševanje ovir grajenega okolja na področju potniškega prometa se nanašajo na potrebo po ureditvi vstopov in izstopov iz prevoznih sredstev ter na splošno na prilagajanje prevoznih sredstev in postajališč. $\mathrm{Za}$ zmanjšanje teh ovir grajenega okolja predstavniki invalidskih organizacij predlagajo ureditev klančin in dvigal, znižanje višin stopnic in robnikov, namestitev klopi na postajališčih, vrat na prevoznih sredstvih $\mathrm{z}$ ustreznimi širinami in rabo nizkopodnih vozil. Predstavniki so predlagali, da bi morali v Sloveniji pripraviti natančen popis glede dostopnosti problematičnih objektov. Glede odpravljanja komunikacijskih ovir pa anketiranci predlagajo ureditev mest nakupa kart in namestitev različnih opozoril, napisov in označb (zvočni signali, svetlobni prikazovalniki itd.). Invalidi posamezniki in tudi predstavniki organizacij izpostavljajo potrebo po doslednejšem upoštevanju obstoječe zakonodaje oziroma ureditvi in spremembah te ter potrebo po doslednejšem upoštevanju potreb invalidov in odpravljanju obstoječih napak.

Odgovornost za izvajanje ukrepov za zmanjševanje ovir grajenega okolja in komunikacijskih ovir na področju potniškega prometa

Po mnenju anketirancev so v Sloveniji za izvajanje ukrepov za zmanjšsevanje ovir grajenega okolja in komunikacijskih ovir na področju potniškega prometa odgovorne predvsem državne institucije in stroka. Invalidi posamezniki so menili, da so za opravljanje obojih ovir najodgovornejša ministrstva, občine in upravne enote. Te so predstavniki invalidov ocenili kot najodgovornejše pri zmanjševanju komunikacijskih ovir, najpomembnejši akter pri zmanjševanju grajenih ovir v potniškem prometu pa je po njihovem mnenju stroka (arhitekti, načrtovalci, gradbeniki, programerji in podobno).

\section{Ovire na področju izobraževanja, usposabljanja in zaposlovanja}

Med ustanove izobraževanja, usposabljanja in zaposlovanja smo uvrstili vrtce, šole, srednje šole, fakultete, ljudske univerze, organizatorje tečajev, podjetja, izvajalce poklicne in zaposlitvene rehabilitacije in podobno.

Na področjih izobraževanja, usposabljanja in zaposlovanja občutijo invalidi posamezniki nekoliko več grajenih kot komunikacijskih ovir - z veliko in zelo veliko grajenimi ovirami se namreč srečuje tretjina, s komunikacijskimi ovirami pa $28 \%$. Delež predstavnikov, ki meni, da se invalidi v Sloveniji na teh področjih srečujejo z mnogimi ovirami, je višji - da se srečujejo invalidi v takšni meri z grajenimi ovirami jih meni nekaj več kot $38 \%$, medtem ko je tistih, ki so takšnega mnenja za komunikacijske ovire, celo več kot polovica (54\%).

Invalidi posamezniki se $\mathrm{z}$ velikimi in zelo velikimi grajenimi ovirami največkrat srečujejo $\mathrm{v}$ osnovnih šolah in pri organizatorjih tečajev, najmanj grajenih ovir pa zaznavajo $\mathrm{v}$ vrtcih ter pri izvajalcih poklicne in zaposlitvene rehabilitacije (preglednica 2). Nasprotno predstavniki organizacij menijo, da se invalidi z ovirami grajenega okolja $\mathrm{v}$ večji meri srečujejo na področju zaposlovanja, $\mathrm{v}$ manjši pa na področju izobraževanja in usposabljanja. V splošnem invalidi posamezniki menijo, da se invalidi na področjih izobraževanja, usposabljanja in zaposlovanja z večjimi komunikacijskimi ovirami srečujejo redkeje kot z grajenimi ovirami, nasprotnega mnenja pa so predstavniki organizacij, ki ocenjujejo, da občutijo invalidi velike in zelo velike komunikacijske ovire pogosteje kot grajene, in sicer na področju izobraževanja in usposabljanja, zlasti pa na področju zaposlovanja. 
Preglednica 2: Srečevanje invalidov z veliko in zelo veliko ovirami grajenega in komunikacijskega okolja na področjih izobraževanja, usposabljanja in zaposlovanja

\begin{tabular}{llll}
\hline Anketiranci & Ustanova/področje & Grajene ovire (\%) & Komunikacijske ovire (\%) \\
\hline \multirow{4}{*}{ invalidi posamezniki } & vrtci & 26,4 & 32,0 \\
\cline { 2 - 4 } & osnovne šole & 39,6 & 30,4 \\
\cline { 2 - 4 } & srednje šole & 35,2 & 25,0 \\
\cline { 2 - 4 } & fakultete & 32,7 & 31,1 \\
\cline { 2 - 4 } & ljudske univerze & 25,5 & 25,6 \\
\cline { 2 - 4 } & organizatorji tečajev & 40,0 & 29,0 \\
\cline { 2 - 4 } & izvajalci poklicne in zaposlitvene rehabilitacije & 33,3 & 42,0 \\
\hline \multirow{2}{*}{ predstavniki organizacij } & izobraževanje in usposabljanje & 35,0 & 58,0 \\
\cline { 2 - 4 } & zaposlovanje & 49,0 & \\
\hline
\end{tabular}

Najpomembnejše ovire grajenega okolja in komunikacijske ovire na področju izobraževanja, usposabljanja in zaposlovanja

Na področju izobraževanja, usposabljanja in zaposlovanja anketiranci v grajenem okolju kot problematične najpogosteje navajajo neprimerne dostope do objektov, v katerih se izvajajo dejavnosti izobraževanja, usposabljanja in zaposlovanja, ter do posameznih prostorov v teh objektih (stopnice, visoki robniki in pragovi, preozka vrata in prehodi, pomanjkanje dvigal in klančin). Predstavniki organizacij v zvezi s tem izpostavljajo predvsem vrtce in šole, omenjajo pa tudi, da za invalide niso urejeni primerni prevozi do šole. Invalidi posamezniki kot problematične navajajo še neprimerno pohištvo v izobraževalnih ustanovah ter ustanovah s področja usposabljanja in zaposlovanja, predstavniki organizacij pa sanitarije, ki invalidom večkrat niso dostopne (preozek prostor za invalidski voziček, previsoke straniščne školjke in podobno). Komunikacijske ovire v izobraževalnih in zaposlitvenih ustanovah so po mnenju invalidov posameznikov predvsem slaba informiranost, otežena komunikacija, slabo prilagojen učni material ter tudi netolerantnost in nesolidarnost šolskih oziroma študijskih kolegov. Predstavniki organizacij izpostavljajo predvsem pomanjkanje tolmačev - v zvezi s tem omenjajo probleme s plačili tolmačev. Gluhi bi po njihovem potrebovali tudi več zapisovalcev predavanj, naglušnim pa bi udeležbo v izobraževalnem in zaposlitvenem procesu lajšale indukcijske zanke, ki bi jih bilo treba vgraditi. Navedene so bile tudi ovire, ki se navezujejo na problem podajanja informacij in znanj (na primer profesorji razlagajo nerazumljivo in prehitro), pomanjkanje prilagojene študijske literature in drugih učnih gradiv, težave se pojavljajo pri branju (na primer na predavanjih), (ne)razumevanju oznak na napravah in navodil za uporabo.

Predlogi za zmanjševanje ovir grajenega okolja ter komunikacijskih ovir na področju izobraževanja, usposabljanja in zaposlovanja

Za zmanjšanje ovir grajenega okolja na področju izobraževanja, usposabljanja in zaposlovanja bi bilo za invalide posameznike najpomembneje urediti zakonodajo, predlagajo pa še, da je treba urediti tudi dostope do posameznih poslopij in izboljšati funkcionalnost zgradb. Glede slednjega menijo podobno tudi predstavniki invalidskih organizacij, oboji pa so mnenja, da je pri iskanju rešitev za ovire obstoječe infrastrukture ter novogradenj nujno tesno sodelovanje $z$ invalidi in invalidskimi organizacijami, arhitekti, fakultetami in urbanisti. Predstavniki organizacij v zvezi s predlogi za zmanjševanje ovir grajenega okolja izpostavljajo tudi nujo po finančni podpori za odpravo teh in vpeljavo davčnih spodbud za odpravljanje grajenih ovir. Za zmanjšanje ovir komunikacijskega okolja na področju izobraževanja, usposabljanja in zaposlovanja bi bilo za invalide posameznike in tudi za predstavnike invalidskih organizacij najpomembneje urediti področje tolmačev. Omogočiti bi bilo treba študij invalidov na daljavo, pridobitev osnovnih komunikacijskih sredstev za invalide na zdravniški recept, pomembne zadeve zapisati v lahko berljivem tekstu (na primer veliki napisi $\mathrm{v}$ barvah in simbolih), postaviti informacijske table na raven, ki bo dostopna tudi za invalide na vozičkih in v šolah omogočiti indukcijske zanke. Komunikacijske ovire bi po mnenju invalidov posameznikov lahko zmanjšala tudi višja stopnja tolerance, enakopravnost in volja ter pripravljenost za pomoč drugim. Menijo, da bi bilo treba ljudi, ki delajo na področju izobraževanja, ustrezno izobraziti in usposobiti za delo z invalidi. Predstavniki invalidov menijo, da bi bilo nujno treba bolj spodbujati zaposlovanje invalidov, zlasti pa »destigmatizirati « to področje. Med predlogi najdemo tudi misel, da je treba izdelati natančen popis objektov na terenu in opozarjati na ovire $s$ konkretnimi primeri ter dolgoročno načrtovati spremembe.

Odgovornost za izvajanje ukrepov za zmanjševanje ovir grajenega okolja ter komunikacijskih ovir na področju izobraževanja, usposabljanja in zaposlovanja

Za izvajanje ukrepov za zmanjševanje ovir grajenega okolja na področju izobraževanja, usposabljanja in zaposlovanja invalidi posamezniki največjo odgovornost za zmanjševanje ovir pripisujejo ministrstvom, predstavniki invalidskih organizacij pa stroki. Na področju komunikacijskih ovir se oboji anketirani strinjajo, da imajo največjo odgovornost državne ustanove (ministrstva, občine in upravne enote). 


\section{Ovire na področju izvajanja storitev zdravstvenega in socialnega varstva}

Med ustanove na področju izvajanja storitev zdravstvenega in socialnega varstva smo uvrstili bolnišnice, zdravstvene domove, ambulante, zdravilišča, centre za socialno delo in podobno.

$\mathrm{Na}$ področjih izvajanja storitev zdravstvenega in socialnega varstva občutijo invalidi posamezniki precej več grajenih kot komunikacijskih ovir - z veliko in zelo veliko grajenimi ovirami se jih namreč srečuje $31 \%$, s komunikacijskimi ovirami pa $18 \%$. Delež predstavnikov invalidskih organizacij, ki meni, da se invalidi v Sloveniji na teh področjih srečujejo z mnogimi ovirami, je približno enak za obe vrsti ovir, vendar v primerjavi $\mathrm{z}$ invalidi posamezniki višji, saj tako meni okoli štiri desetine vprašanih.

Med ustanovami, $\mathrm{v}$ katerih izvajajo storitve zdravstvenega in socialnega varstva, glede velikega števila grajenih ovir, ki jih občutijo invalidi posamezniki, najbolj izstopajo centri za socialno delo in tudi glede komunikacijskih ovirah so te ustanove na prvem mestu, vendar pa je razlika v deležih odgovorov invalidov posameznikov, ki menijo, da se s precejšnjimi komunikacijskimi ovirami srečujejo tudi v varnih hišah in materinskih domovih ter domovih za starejše, v primerjavi z grajenim ovirami precej nižja (preglednica 3). Mnenja predstavnikov organizacij glede srečevanja invalidov z ovirami na področju koriščenja storitev zdravstvenega in socialnega varstva so veliko bolj izenačena, in sicer glede grajenih ovir skoraj povsem, glede komunikacijskih ovir pa je nekoliko višji delež predstavnikov, ki menijo, da se invalidi z velikimi in zelo velikimi komunikacijskimi ovirami pogosteje srečujejo ovirami v ustanovah zdravstvenega varstva.

Najpomembnejše ovire grajenega okolja in komunikacijske ovire na področju izvajanja storitev zdravstvenega in socialnega varstva

Invalidi posamezniki in predstavniki invalidskih organizacij glede grajenih ovir pri objektih, v katerih se izvajajo stori- tve zdravstvenega in socialnega varstva, navajajo dostop do teh objektov in prostorov v njih (ozki hodniki, pomanjkanje ročajev, pomanjkanje svetlobnih javljanj, premalo kontrastnih označb). V teh ustanovah pogosto tudi nimajo (dovolj) ustrezno opremljenih sanitarij, izpostavljajo pa tudi neprilagojeno diagnostično opremo. Kot komunikacijsko oviro anketirani najprej navajajo neustrezno in oteženo sporazumevanje z uradnim osebjem, invalidi posamezniki pa posebej opozarjajo na pomanjkanje empatije, prijaznosti in strpnosti zaposlenih do invalidov. Omenjeni so tudi previsoki pulti in zastekljena okenca, kar še dodatno otežuje komunikacijo z osebjem, pogosto so za slepe neprilagojeni tudi terminali, po mnenju predstavnikov invalidov je tudi slaba dostopnost tehničnih pripomočkov za gluhe in naglušne, pomanjkanje indukcijskih zank, tolmačev in podobno.

Predlogi za zmanjševanje ovir grajenega okolja in komunikacijskih ovir na področju izvajanja storitev zdravstvenega in socialnega varstva

Za zmanjšanje ovir grajenega okolja na področju izvajanja storitev zdravstvenega in socialnega varstva bi bilo po mnenju anketiranih najpomembneje urediti dvigala, sanitarije, dovoze do zgradb, parkirišča (povečati število parkirišč za invalide). Poleg tega bi bilo treba urediti zakonodajo in dosledno izvajati obstoječo zakonodajo ter $\mathrm{v}$ zvezi s tem povečati nadzor in sankcije. Menijo, da bi bilo treba upoštevati tudi mnenja invalidov. Ker se komunikacijske ovire na področju izvajanja storitev zdravstvenega in socialnega varstva po mnenju anketiranih najpogosteje pojavljajo v sporazumevanju z osebjem, bi bilo treba zaposliti več ustrezno izobraženih tolmačev. Predstavniki invalidskih organizacij izpostavljajo tudi potrebo po splošnem izobraževanju in usposabljanju zaposlenih za delo z invalidi. Drugi predlogi so še: svetlobne označbe in napisi (prikazovalniki), klic prek prikazovalnika, naročanje prek sms-a, pisne informacije, indukcijske zanke, portali z informacijami. S strani predstavnikov invalidskih organizacij je bila izpostavljena potreba po natančnem popisu neustreznih objektov na terenu, na podlagi konkretnih primerov pa opozarjanje javnosti o teh problemih.

Preglednica 3: Srečevanje invalidov z veliko in zelo veliko ovirami grajenega in komunikacijskega okolja na področju izvajanja storitev zdravstvenega in socialnega varstva

\begin{tabular}{llll}
\hline Anketiranci & Ustanova/področje & Grajene ovire (\%) & Komunikacijske ovire (\%) \\
\hline & bolnišnice & 13,2 & 31,6 \\
\cline { 2 - 4 } & zdravstveni domovi & 18,5 & 28,8 \\
\cline { 2 - 4 } invalidi posamezniki & ambulante & 15,5 & 26,1 \\
\cline { 2 - 4 } & zdravilišča & 14,9 & 25,3 \\
\cline { 2 - 4 } & centri za socialno delo & 35,9 & 31,5 \\
\cline { 2 - 4 } & domovi za starejše občane & 11,6 & 32,6 \\
\cline { 2 - 4 } & varne hiše, materinski domovi & 18,8 & 39,0 \\
\hline \multirow{2}{*}{ predstavniki organizacij } & zdravstveno varstvo & 39,0 & 44,0 \\
\cline { 2 - 4 } & socialno varstvo & 40,0 & 39,0 \\
\hline
\end{tabular}


Odgovornost za izvajanje ukrepov za zmanjševanje ovir grajenega okolja in komunikacijskih ovir na področju izvajanja storitev zdravstvenega in socialnega varstva

Anketirani menijo, da so za izvajanje ukrepov za zmanjševanje ovir grajenega okolja in komunikacijskih ovir na področju izvajanja storitev zdravstvenega in socialnega varstva najbolj odgovorne državne ustanove - ministrstva, upravne enote in občine -, pomembno odgovornost nosijo tudi stroka in izvajalci storitev. Tako meni, ne glede na obliko ovir, več kot $90 \%$ vseh anketirancev.

\section{Ovire pri dostopu do storitev državne uprave}

Kot ustanove državne uprave smo opredelili občine, upravne enote, sodišča, davčne urade enote za zaposlovanje, pokojninsko in invalidsko zavarovanje, zdravstveno zavarovanje in podobno.

Pri dostopu do storitev državne uprave se srečuje z velikimi in zelo velikimi ovirami grajenega in komunikacijskega okolja približno enak delež invalidov, in sicer je delež prvih 41-odstoten, delež drugih pa 45-odstoten, kar je primerljivo z vrednostmi pri dostopnosti do storitev potniškega prometa. Delež predstavnikov invalidov, ki so glede obsega obeh oblik ovir enakega mnenja, je še višji - več kot polovica predstavnikov namreč meni, da se njihovi člani in članice pri dostopu do storitev državne uprave srečuje s precejšnjimi grajenimi in komunikacijskimi ovirami.

Največ grajenih ovir zaznavajo invalidi posamezniki pri dostopu do storitev sodnih organov, na drugem mestu pa so občine. Glede komunikacijskih ovir prav tako izstopajo sodišča, $s$ to vrsto ovir pa se invalidi zelo pogosto srečujejo tudi v davčnih uradih in enotah za zaposlovanje (preglednica 4). Predstavniki organizacij menijo, da se invalidi pri storitvah državne uprave pogosteje srečujejo komunikacijskimi ovirami.
Najpomembnejše ovire grajenega okolja in komunikacijske ovire pri dostopu do storitev državne uprave

Na področju dostopa do storitev državne uprave se kot ovira grajenega okolja pojavlja nedostopnost posameznih prostorov in objektov (ozka in neprilagojena - na primer steklena - vrata, previsoki pragovi, stopnice, pomanjkanje dvigal). Po mnenju predstavnikov organizacij so za invalide neprilagojene predvsem starejše zgradbe. Anketirani kot problematične izpostavljajo tudi neprilagojene in nedostopne sanitarije za invalide ter tudi premajhno število parkirišč za invalide pred ustanovami državne uprave. Glede komunikacijskih ovir izpostavljajo probleme $s$ tolmači (neenakomerna regijska pokritost $s$ tolmači, problem pomanjkanja tolmačev, zlasti na sodiščih in podobno), potrebo po posebnih tehničnih pripomočkih (premajhna je velikost napisov, premalo je zvočnih oznak, podnapisov in podobno), težave državnih uradov pri informiranju in obveščanju invalidov, težave z obrazci in navodili, ki so pogosto napisani zapleteno in nerazumljivo, ter težave pri sporazumevanju z osebjem (kontaktna okenca, ki so zatemnjena, previsoka, zvonci so pogosto nameščeni previsoko in podobno), invalide posameznike pa pogosto moti tudi neprijaznost osebja.

Predlogi za zmanjševanje ovir grajenega okolja in komunikacijskih ovir pri dostopu do storitev državne uprave

Za odpravo grajenih ovir invalidi posamezniki predlagajo spremembo zakonodaje in prilagajanje naše zakonodaje evropski. Anketiranci predlagajo ureditve in popravke starih gradenj ter več sredstev za odpravljanje takih arhitektonskih ovir (na primer za vgradnjo dvigal). Pri tem izpostavljajo potrebo po komunikaciji med izvajalci gradbenih del in invalidi (uporabniki). Med predlogi za zmanjšanje ovir komunikacijskega okolja na področju dostopa do storitev državne uprave se največkrat pojavlja potreba po zagotoviti tolmača $\mathrm{v}$ vseh uradih državne uprave, invalidi posamezniki pa posebej izpostavljajo željo po večji strpnosti, prijaznosti in kulturi v sporazumevanju v držav-

Preglednica 4: Srečevanje invalidov z veliko in zelo veliko ovirami grajenega in komunikacijskega okolja pri dostopu do storitev državne uprave

\begin{tabular}{llll}
\hline Anketiranci & Ustanova/področje & Grajene ovire (\%) & Komunikacijske ovire (\%) \\
\hline & občine & 45,5 & 43,3 \\
\cline { 2 - 4 } & upravne enote & 42,9 & 42,1 \\
\cline { 2 - 4 } invalidi posamezniki & sodišča & 50,0 & 50,6 \\
\cline { 2 - 4 } & davčni uradi & 42,0 & 47,5 \\
\cline { 2 - 4 } & enote zavoda za zaposlovanje & 39,7 & 47,9 \\
\cline { 2 - 4 } & enote zavoda za pokojninsko in invalidsko & 34,1 & 43,3 \\
& zavarovanje & 30,2 & 39,8 \\
\cline { 2 - 4 } & enote zavoda za zdravstveno zavarovanje & 51,0 & 53,0 \\
\hline predstavniki organizacij & storitve državne uprave & &
\end{tabular}


nih uradih. Po mnenju predstavnikov organizacij bi bilo treba za zmanjšanje grajenih in komunikacijskih ovir pri dostopu do storitev državne uprave upoštevati obstoječo zakonodajo, predpise, strategije, kršitelje pa kaznovati. Menijo, da bi bilo treba zbrati mnenja invalidov in organizirati izobraževanja, informiranja in seznanjanja uslužbencev o različnih oblikah invalidnosti. Natančno bi bilo treba pregledati stanje na terenu, narediti ustrezne sezname, neprilagojene objekte obnoviti in vse oblike javnosti opozoriti na to problematiko.

Odgovornost za izvajanje ukrepov za zmanjševanje ovir grajenega okolja in komunikacijskih ovir pri dostopu do storitev državne uprave

Anketiranci so največjo odgovornost za izvajanje ukrepov na področju zmanjševanje ovir grajenega in komunikacijskega okolja pri dostopu do storitev državne uprave pripisali izvajalcem storitev - gre za ministrstva, upravne enote, občine, sodišča, davčne urade -, velik del odgovornosti bi po njihovem morala prevzeti tudi stroka - arhitekti, načrtovalci, gradbeniki, programerji in podobno.

\section{Ovire pri dostopu do ponudbe kulturnih ustanov}

Med kulturne ustanove smo uvrstili gledališča, muzeje, galerije, kulturne domove, koncertne dvorane, knjižnice, kinematografe in podobno.

$\mathrm{Z}$ velikimi in zelo velikimi ovirami grajenega in komunikacijskega okolja se pri dostopu do ponudbe kulturnih ustanov srečuje enak delež invalidov (39\%). Po mnenju predstavnikov invalidskih organizacij je ta delež višji, in sicer 45-odstoten pri ovirah grajenega okolja in 48-odstoten pri komunikacijskih ovirah.

$\mathrm{Z}$ največ ovirami grajenega okolja so invalidi soočeni v muzejih, najbolj invalidom prijazen pa je dostop do ponudbe kinematografov in knjižnic (preglednica 5). Po mnenju invalidov posameznikov so glede komunikacijskih ovir za invalide najmanj ugodne koncertne dvorane, podobno pa velja tudi za kulturne domove, galerije in gledališča, z najmanj komunikacijskimi ovirami pa se invalidi srečujejo v knjižnicah.

Najpomembnejše ovire grajenega okolja in komunikacijske ovire pri dostopu do ponudbe kulturnih ustanov

Po mnenju invalidov posameznikov in predstavnikov invalidskih organizacij je najpogostejša grajena ovira na področju dostopa do ponudbe kulturnih ustanov nedostopnost objektov in prostorov (problem so stopnice, premalo je dvigal in klančin, slednje so ponekod prestrme, preozki so tudi vhodi in prehodi ter vrata so pogosto pretežka). V kulturnih ustanovah so za invalide pogosto nedostopne ali niso ustrezne tudi sanitarije in garderobe. Navajajo še pomanjkanje parkirišč za invalide pred kulturnimi ustanovami, neurejene dovoze do zgradb in podobno. Pri komunikacijskih ovirah invalidi posamezniki izpostavljajo problem $s$ sporazumevanjem z zaposlenim osebjem, ki se najpogosteje pojavlja v muzejih in galerijah, sledijo pa jim gledališča in opera. Problematična so tudi zastekljena in previsoka okenca pri pultih za nakup kart, dolge čakalne vrste, premajhni podnapisi v kinematografih, previsoko obešene slike v galerijah, slabo ozvočenje in podobno. Predstavniki organizacij navajajo še težave invalidov pri rezervaciji in nakupu kart, premajhne napise in označbe, premajhno pisavo $\mathrm{v}$ tiskovinah kulturnih ustanov, pomanjkanje besedil v lahko berljivi tehniki ter nekakovostno in premalo ažurno obveščanje. Po mnenju vseh anketiranih je premalo tolmačev in indukcijskih zank $\mathrm{v}$ prostorih in dvoranah s področja kulture.

Predlogi za zmanjševanje ovir grajenega okolja in komunikacijskih ovir pri dostopu do ponudbe kulturnih ustanov

Za zmanjšanje ovir grajenega okolja na področju dostopa do ponudbe kulturnih ustanov anketirani navajajo, da bi bilo treba prilagoditi in izboljšati dostope do stavb: izgradnja klančin, tekočih stopnice in dvigal, ureditev navadnih stopnic z držali in ograjami, zmanjšanje in odstranitev pragov, zmanjšanje ravni pločnikov, vgraditev širših vrat in ureditev parkirišč. Predlagajo tudi ureditev sanitarij, predstavniki invalidov pa tudi postavitev reliefnih talnih oznak znotraj kulturnih ustanov. Invalidi

Preglednica 5: Srečevanje invalidov z veliko in zelo veliko ovirami grajenega in komunikacijskega okolja pri dostopu do ponudbe kulturnih ustanov

\begin{tabular}{llll}
\hline Anketiranci & Ustanova/področje & Grajene ovire (\%) & Komunikacijske ovire (\%) \\
\hline & gledališča & 40,1 & 40,0 \\
\cline { 2 - 4 } & muzeji & 50,7 & 37,6 \\
\cline { 2 - 4 } galerije & 40,0 & 40,7 \\
\cline { 2 - 4 } invalidi posamezniki & kulturni domovi & 41,1 & 41,2 \\
\cline { 2 - 4 } & koncertne dvorane & 44,6 \\
\cline { 2 - 4 } & knjižnice & 32,6 & 33,3 \\
\cline { 2 - 4 } & kinematografi & 25,9 & 37,5 \\
\hline predstavniki organizacij & dostop do ponudbe kulturnih ustanov & 45,0 & 48,0 \\
\hline
\end{tabular}


posamezniki se zavzemajo za ureditev zakonodaje predvsem na področju novih gradenj in po sprejetju ustreznih finančnih okvirov za ureditev tega področja ter predvsem nadzor in sankcije pri kršenju zakonodaje. V zvezi z zmanjšanjem komunikacijskih ovir predlagajo predstavniki invalidov uvedbo posebnih okenc ali prostorov za invalide. Po njihovem bi bilo treba postaviti tudi posebne portale $\mathrm{z}$ informacijami za invalide, pisne informacije bi morali opremiti s slikami, z Braillovo pisavo in zvokom, vse projekcije pa bi morale biti opremljene s podnapisi. Predstavniki invalidov in invalidi sami so izpostavili potrebo po tolmačih (za gluhe), za naglušne pa boljši dostop do indukcijskih zank. Invalidi posamezniki tudi želijo, da so mnenja invalidov in nevladnih organizacij dosledneje upoštevana, predstavniki organizacij pa se zavzemajo za spoštovanje obstoječe zakonodaje na tem področju, predpisov in strategij. Za odpravljanje grajenih in komunikacijskih ovir je bil podan tudi zanimiv predlog o posebnih davčnih spodbudah na tem področju. Predstavniki organizacij omenjajo še, da bi bilo treba glede grajenih in komunikacijskih ovir izvesti natančne popis stanja na terenu, na nepravilnosti opozoriti in izvesti potrebno obnovo. Ob vsem tem pa zbrati tudi mnenja in stališča invalidov. Poudarjeno je bilo, da bi bilo treba na nedostopnost storitev v kulturi opozoriti s konkretnimi primeri.

Odgovornost za izvajanje ukrepov za zmanjševanje ovir grajenega okolja in komunikacijskih ovir pri dostopu do ponudbe kulturnih ustanov

Največ odgovornosti za izvajanje ukrepov za zmanjševanje ovir grajenega okolja in komunikacijskih ovir na področju kulturnih ustanov po mnenju invalidov in njihovih predstavnikov državne ustanove (ministrstva, občine in upravne enote), ponudniki storitev in stroka, pri čemer ima stroka večjo odgovornost za zmanjševanju grajenih kot komunikacijskih ovir.

\section{Ovire pri aktivnostih preživljanja prostega časa (šport, rekreacija in turizem)}

Med prostore za opravljanje aktivnosti preživljanja prostega časa smo šteli: športne dvorane, zunanje športne objekte, bazene, nastanitvene zmogljivosti za turistične namene (sobe, apartmaji, bungalovi in podobno), gostinske lokale (restavracije, gostilne, bari, nočni klubi in podobno).

Invalidi posamezniki menijo, da se pri aktivnostih prostega časa z velikimi in zelo velikimi ovirami pogosteje srečujejo v grajenem okolju (tako jih meni 35,2 \%) kot v komunikacijskem (26,2 \%). Predstavniki organizacij pa navajajo, da je pri opravljanju aktivnosti prostega časa za invalide precej več komunikacijskih ovir (tako jih meni 58,8 \%). V splošnem je delež predstavnikov, ki meni, da se pri teh dejavnostih njihovi člani in članice pogosto srečujejo $\mathrm{z}$ velikimi in zelo velikimi ovirami, višsi kot delež invalidov posameznikov, ta pa tudi pri grajenih ovirah znaša več kot $40 \%$.
Po mnenju invalidov posameznikov so glede grajenih ovir najbolj problematični bazeni, podobno velja za gostinske lokale in nastanitvene zmogljivosti za turistične namene, najmanj problematični pa so zunanji športni objekti (preglednica 6). Slednji so najmanj problematični tudi glede komunikacijskih ovir, največ težav pa imajo invalidi z njimi v športnih dvoranah in gostinskih lokalih. Predstavniki invalidskih organizaciji so enotnejši, saj menijo, da se invalidi soočajo z velikimi in zelo velikimi grajenimi ovirami ter $s$ komunikacijskimi ovirami v približno enaki meri pri izvajanju športno-rekreativnih dejavnostih in tudi v turizmu.

Najpomembnejše ovire grajenega okolja in komunikacijske ovire pri aktivnostih preživljanja prostega časa

$\mathrm{Za}$ anketirane so najbolj problematične ovire grajenega okolja pri aktivnostih prostega časa stopnice, visoki robnik, preozka vrata, neprilagojene ali neprimerne, premajhne ali nedostopne sanitarije, problematične so tudi neurejene poti, preozki prehodi in dostop do bazenov (na primer mokra tla) in preozke kabine za preoblačenje oziroma po mnenju predstavnikov organizacij kabine pogosto sploh niso prilagojene za invalide. Invalidi posamezniki zaznavajo grajene ovire tudi v gostiščih, ki so pogosto dostopna le poleti, ko so urejeni zunanji vrt, za invalide pogosto niso prilagojeni tudi nastanitveni objekti (apartmaji, bungalovi, hoteli), vlečnice na smučǐščih (na primer prehitre), tribune za gledalce niso dostopne in podobno. Kot ovire komunikacijskega okolja pri aktivnostih preživljanja prostega časa invalidi posamezniki največkrat navajajo sporazumevanje z osebjem, nedostopnost tolmačev, pomanjkanje navodil, oznak, napisov in podnapisov, ki so velikokrat tudi premajhni. Kot problematičen navajajo tudi hrup v prostorih in dvoranah, kjer težko komunicirajo, ter težavo pri tem, da pritegnejo pozornost nase in svoje potrebe. Invalidi izražajo potrebo po zvočni signalizaciji in boljši osvetljenosti v objektih. Izpostavljajo tudi potrebo po tem, da bi morale biti informacije na spletu redno ažurirane, da bi moralo biti več popustov za invalide, več pomoči pri namestitvah in naročanju v lokalih. Med osebjem zaznavajo nerazumevanje drugačnosti, premalo tolerance in spoštovanja, torej neusposobljenost za delo z invalidi. Predstavniki organizacij še posebej izpostavljajo premalo turističnih programov, prilagojenih invalidom, in tudi, da turistični vodniki ne znajo znakovnega jezika.

Predlogi za zmanjševanje ovir grajenega okolja in komunikacijskih ovir pri aktivnostih preživljanja prostega časa

Za zmanjšanje ovir grajenega okolja pri aktivnostih prostega časa invalidi predlagajo, da bi bilo treba nadomestiti stopnice $s$ klančinami in z dvigali, smiselno bi bilo urediti zakonodajo, predvsem v zvezi z novimi gradnjami. Nekateri so izpostavili potrebo po ureditvi pločnikov ter sprehajalnih in kolesarskih 
Preglednica 6: Srečevanje invalidov z veliko in zelo veliko ovirami grajenega in komunikacijskega okolja pri aktivnostih preživljanja prostega časa

\begin{tabular}{llll}
\hline Anketiranci & Ustanova/področje & Grajene ovire (\%) & Komunikacijske ovire (\%) \\
\hline \multirow{4}{*}{ invalidi posamezniki } & športne dvorane & 29,0 & 33,8 \\
\cline { 2 - 4 } & zunanji športni objekti & 18,8 & 16,6 \\
\cline { 2 - 4 } & bazeni & 43,4 & 24,2 \\
\cline { 2 - 4 } & nastanitev zmogljivosti za turistične namene & 40,2 & 22,8 \\
\cline { 2 - 4 } & gostinski lokali & 41,0 & 31,3 \\
\hline \multirow{2}{*}{ predstavniki organizacij } & izvajanje športno-rekreativnih dejavnosti & 41,0 & 58,0 \\
\cline { 2 - 4 } & turizem & 43,0 & 59,0 \\
\hline
\end{tabular}

stez, ureditvi sob za invalide $\mathrm{v}$ hotelih in apartmajih, ureditvi stopnǐ̌c ter prilagoditvi terena in vrat. Nekateri so kot predlog izpostavili tudi več sredstev, upoštevanje mnenja invalidov, osveščanje in upoštevanje stroke. $S$ strani predstavnikov organizacij so bili podani predlogi po ureditvi parkov, igriščc, telovadnic, poti, dograditvi garderob za invalide, ureditvi dvigal in klančin, bazenov (ročaji, dvigala), stadionov (dvigala) in lokalov. Pri starejših objektih bi bile večinoma potrebne obnove in prilagoditve objektov invalidom. Izpostavljeno je še bilo, da bi bilo treba zagotoviti več osebnih asistentov, ki pa ne pomenijo zmanjšanja grajenih ovir za invalide, temveč jim premagovanje teh le olajšajo. Predstavniki invalidov med predlogi za zmanjšanje ovir komunikacijskega okolja pri izvajanju aktivnosti preživljanja prostega najbolj izpostavljajo izboljšanje dostopnosti različnih informacij, invalidi posamezniki pa izražajo željo po tolmačih. V splošnem anketirani menijo, da bi morali invalide z različnimi ovirami vprašati, kaj konkretno potrebujejo, prav tako pa bi morali upoštevati mnenje stroke in invalidskih organizacij. Navedeno je bilo, da bi morali javno opozoriti na nedostopnost objektov, odgovorne pa sankcionirati oziroma opozoriti na kršitve s predstavitvijo konkretnih primerov.

Odgovornost za izvajanje ukrepov za zmanjševanje ovir grajenega okolja in komunikacijskih ovir pri aktivnostih preživljanja prostega časa

Po mnenju anketirancev so pri aktivnostih preživljanja prostega časa za izvajanje ukrepov za zmanjševanje ovir (tako grajenih kot tudi komunikacijskih) odgovorni predvsem stroka, institucije in ponudniki storitev, za odpravljanje grajenih ovir pa predvsem stroka (arhitekti, prostorski načrtovalci, gradbeniki in podobno).

\section{Glavne ugotovitve in sklep}

Empirična raziskava je pokazala, da je bilo v Sloveniji za uresničevanje pravic invalidov, ki so zapisane in opredeljene $\mathrm{v}$ številnih nacionalnih in mednarodnih dokumentih, do sedaj narejenega premalo. Invalidi se zato še vedno srečujejo s številnimi ovirami grajenega in komunikacijskega okolja. Primerjava odgovorov anketiranih invalidov posameznikov in predstavnikov invalidskih organizacij kaže, da so odgovori glede ugotovljenih ovir večinoma zelo podobni. To pomeni, da predstavniki invalidskih organizacije dobro poznajo težave svojih članov in ovire, s katerimi se ti srečujejo, kar se od predstavnikov tudi pričakuje. Pomeni pa tudi, da ovire dejansko obstajajo ter da pomenijo za invalide velik in splošen problem.

Glede grajenih ovir so bile med anketiranimi kot največja ovira skoraj vedno omenjene stopnice. $\mathrm{Na}$ drugem mestu je bil najpogosteje omenjen neobstoj klančin oziroma dejstvo, da so te prestrme, tem sledijo visoki robniki in pločniki, pogosto pokvarjena dvigala, pomanjkanje ročajev oziroma držal, preozka vrata oziroma preozki prehodi, za invalide neustrezno opremljene oziroma nedostopne sanitarije in podobno. Pomembna je tudi ugotovitev, da se pri grajenih ovirah na vseh področjih, ki jih je raziskava obsegala, večinoma pojavljajo enake ovire.

Pri ovirah komunikacijskega okolja je drugače. Ovire, ki so jih anketiranci izpostavili, se namreč razlikujejo glede na področje družbenega življenja. Kljub temu lahko povzamemo najpogosteje omenjene komunikacijske ovire. Posamezni invalidi in tudi predstavniki organizacij so $\mathrm{v}$ anketi velikokrat omenili neustrezno oziroma oteženo sporazumevanje z osebjem na eni strani in neprijaznost oziroma nerazumevanje težav invalidov s strani splošne javnosti na drugi. Veliko oviro pomenijo tudi sistemi obveščanja, ki so večinoma niso ustrezni za potrebe invalidov. Pri tem so bili največkrat omenjeni: neberljivi napisi, pomanjkljiva navodila, neobstoj oznak, pomanjkanje signalizacij, slaba osvetljenost, slabo ozvočenje, neustrezno postavljena okenca informatorjev in podobno. Za gluhe in naglušne pomeni posebej veliko oviro pomanjkanje oziroma neobstoj tolmačev.

Za zmanjšanje ovir grajenega in komunikacijskega okolja so anketirani navedli več koristnih in uporabnih predlogov ukrepov, ki se med seboj razlikujejo glede na obravnavano področje. Več predlaganih ukrepov je že vsebovanih v strategiji Dostopna Slovenija ali pa v Akcijskem programu za invalide 2007-2013, kar potrjuje, da so avtorji teh dokumentov izhajali iz dejanskih potreb. $S$ tem pa se je potrdila tudi vodilna hipoteza raziskave, da je za neučinkovito izvajanje ukrepov najbolj krivo nedosledno oziroma nezadostno upoštevanje ali sploh 
neupoštevanje zakonov in drugih predpisov, ki se nanašajo na pravice invalidov.

Za izboljšanje stanja na področju potniškega prometa poudarjata obe skupini anketiranih potrebo po upoštevanju zakonodaje, potrebo po večjem nadzoru nad izvajanjem te in potrebo po spremembah te. Predstavniki organizacij predlagajo izvedbo natančnega popisa dostopnosti problematičnih objektov na terenu, invalidi pa opozarjajo, da bi se morali projektanti, investitorji in izvajalci pred ureditvami potniškega prometa posvetovati z invalidi.

$\mathrm{Na}$ področju izobraževanja, usposabljanja in zaposlovanja sta obe skupini vprašanih, poleg ukrepov, povezanih z ureditvijo oziroma dopolnitvijo nove zakonodaje in nadzorom nad izvajanjem obstoječe, predlagali zagotavljanje večje finančne podpore. Finančno bi bilo treba podpreti ukrepe, namenjene zmanjševanju ovir in izboljšanju dostopnosti, in uvesti davčne spodbude za odpravo ovir. Medtem ko invalidske organizacije pri ukrepih na področju komunikacij predlagajo predvsem različne tehnične ukrepe in rešitve, invalidi poudarjajo potrebo po izboljšanju osveščenosti, večji toleranci, enakopravnost, volji in pripravljenost za pomoč drugim, tako v izobraževalnih okoljih kot tudi na delovnih mestih. Invalidske organizacije navajajo še potrebo po destigmatizaciji invalidov na področju izobraževanja, usposabljanja in zaposlovanja.

Tudi na področju izvajanja dejavnosti zdravstvenega in socialnega varstva obe skupini anketiranih opozarjata na nedosledno izvajanje zakonodaje. Pri izvajanju storitev zdravstvenega in socialnega varstva so grajene ovire predvsem slabi dostopi (klančine sicer so, vendar nimajo ustreznih naklonov), slabo delovanje dvigal (dvigala so, vendar zaradi nerednega vzdrževanja pogosto ne delujejo), težave pri dovozu (parkirišča za invalide sicer so, vendar so na njih parkirani avtomobili neinvalidov) in podobno. Podobno kot na področju izobraževanja in zaposlovanja si invalidi pri sporazumevanju želijo več prijaznosti in strpnosti zaposlenih $\mathrm{v}$ ustanovah zdravstvenega in socialnega varstva in povečanje osebnega stika zaposlenih $\mathrm{z}$ invalidi.

Glede dostopa do storitev državne uprave predstavniki invalidskih organizacij med drugim predlagajo selitev dejavnosti $\mathrm{v}$ primernejše, za invalide dostopnejše prostore, sicer pa obe skupini predlagata doslednejše upoštevanje in izvajanje obstoječih zakonov. Tudi za to področje so predstavniki invalidov predlagali popis stanja na terenu in na ta način možnost opozarjanja na objekte, ki za invalide niso dostopni.

Predlagani ukrepi za izboljšanje dostopnosti grajenega okolja pri ponudbi kulturnih ustanov so podobni kot pri prejšnjih področjih, na področju komunikacijskih ovir pa je pri obeh skupinah izpostavljena potreba po večjem številu tolmačev, vgradnji in dostopnosti indukcijskih zank, zagotavljanju informacij v Braillovi pisavi in opremljanju predstav s podnapisi.

Pri predlogih ukrepov za zmanjšanje ovir pri dostopnosti do aktivnosti preživljanja prostega časa so predstavniki invalidskih organizacij navedli veliko večji nabor ukrepov kot invalidi posamezniki. V telovadnicah, bazenih in na stadionih bi bilo treba za invalide prilagoditi vhode, vrata, prehode, dvigala, klančine, ročaje, sanitarije in garderobe. Podobno bi bilo po njihovem mnenju treba urediti tudi lokale. Invalidi še opozarjajo, da bi bilo treba tudi v hotelskih kapacitetah vselej zagotoviti ustrezen del prilagojene kapacitete.

Anketirani za izvajanje ukrepov za zmanjševanje ovir (grajenih in tudi komunikacijskih) odgovornost za odpravljanje teh ovir večinoma pripisujejo državnim organom (ministrstvom oziroma upravnim enotam in občinam). Glede odgovornosti je zelo pogosto izpostavljena tudi stroka (arhitekti, prostorski načrtovalci, gradbeniki in podobno), sledijo izvajalci storitev in invalidske organizacije. Ne glede na področje se čutijo invalidi in njihovi bližnji za najmanj odgovorne.

Empirična raziskava je pokazala predvsem dvoje: prvič, da se zakoni in predpisi, ki se nanašajo na odstranitev obstoječih oziroma preprečitev nastajanja novih ovir, v praksi slabo oziroma nezadovoljivo izvajajo, in drugič, da večina ukrepov, ki so bili v različnih dokumentih določeni za odpravljanje ovir in omogočanje gibanja brez ovir, še vedno ni uresničena. $\mathrm{Ob}$ doslednem spoštovanju pomembnih zakonskih določb je treba predloge ukrepov pretvoriti iz črk na papirju v konkretne dejavnosti v družbi oziroma na terenu. Vendar pa treba poleg sprejemanja zakonov in določanja ukrepov za izboljšanje stanja na tem področju nujno narediti še korak naprej. Predlog za dodaten ukrep, ki bi prispeval k učinkovitejšemu reševanju problemov na tem področju, so v raziskavi dali anketiranci sami - konkretneje, predstavniki invalidskih organizacij. Predlagali so, da bi bilo treba natančno pregledati stanje na terenu, da bi se ugotovile obstoječe ovire, pripraviti bi bilo treba ustrezne sezname teh, odgovorne opozoriti na ugotovljene pomanjkljivosti in od njih zahtevati, naj se nepravilnosti čim prej odpravijo. Predlog je po našem mnenju pomemben vzvod, ki bo končno privedel do izvajanja konkretnih ukrepov za uresničevanje pravic invalidov do dostopa brez ovir. To pa je tudi izhodišče za nadaljevanje dela pri našem raziskovalnem projektu.

Dr. Richard Sendi, univ. dipl. inž. arh., znanstveni svetnik Urbanistični inštitut Republike Slovenije, Ljubljana, Slovenija E-pošta: richard.sendi@uirs.si

Dr. Boštjan Kerbler - Kefo, univ. dipl. geogr., asistent z doktoratom Urbanistični inštitut Republike Slovenije, Ljubljana, Slovenija E-pošta: bostjan.kerbler@uirs.si 


\section{Viri in literatura}

Balchin, P., in Rhoden, M. (ur.) 1998): Housing: The essential foundations. London, Routledge.

Barlow, J. in Venables, T. (2004): Will technological innovation create the true lifetime home? Housing Studies, 19(5), str. 795-810.

Brenton, M. (2001): Older people's cohousing communitie. V: Peace, M. S., in Holland, C. (ur.): Inclusive housing in an ageing society. Innovative approaches, str. 169-188. Bristol, Policy Press.

Bulos, M., in Teymur, N. (ur.) (1993): Housing: Design, research, education. Aldershot, Avebury.

Burns, N. (2004): Negotiating difference: Disabled people's experiences of housebuilders. Housing Studies, 19(5), str. 765-780.

Dewsbury, G., Rouncefield, M., Clarke, K., in Sommerville, I. (2004): Depending on digital design: Extending inclusivity. Housing Studies, 19(5), str. 811-825.

Ellison, N., in Burrows, R. (2007): New spaces of (dis)engagement? Social politics, urban technologies and the rezoning of the city. Housing Studies, 22(3), str. 295-312.

Fisk, M. J., (2001): The implication of smart home technologies. V: Peace, M. S., in Holland, C. (ur.): Inclusive housing in an ageing society. Innovative approaches, str. 101-124. Bristol, The Policy Press.

Hanson, J. (2001): From special needs to lifestyle choices. V: Peace, M. S., in Holland, C. (ur.): Inclusive housing in an ageing society. Innovative approaches, str. 29-52. Bristol, The Policy Press.

Harrison, M., in Davis C. (2001): Housing, social policy and difference: Disability, ethnicity, gender and housing. Bristol, The policy Press.

Harrison, M. (2004): Defining housing quality and environment: Disability, standards and social factors. Housing Studies, 19(5), str. 691-708.

Heywood, F. (2004): Understanding needs: A starting point for quality. Housing Studies, 19(5), str. 685-690.

Imrie, R. (2004a): Disability, embodiment and the meaning of home. Housing Studies, 19(5), str. 745-763

Imre, R. (2004b) Housing quality, disability and domesticity. Housing Studies, 19(5), str. 685-690.

Internet 1: www.design.ncsu.edu/cud/about_ud/udprinciplestext. htm (sneto 14. 8. 2008).

Internet 2: http://www.warrington.gov.uk/Housing/Privatehousing/ lifetime_homes_standard.aspx (sneto 14. 8. 2008).

Internet 3: http://www.svz.gov.si/fileadmin/svz.gov.si/pageuploads/ Primarna_zakonodaja/Amsterdamska.pdf (sneto 14. 8. 2008).

Internet 4: http://eur-lex.europa.eu/LexUriServ/LexUriServ.do?uri=D D:05:04:32000L0078:SL:PDF (sneto 14. 8. 2008).

Kelly, M. (2001): Lifetime homes. V: Peace, M. S., in Holland, C. (ur.): Inclusive housing in an ageing society. Innovative approaches, str. 55-75. Bristol, The Policy Press.

Kobal, B., Tjaša, Ž., in Smole, S. (2004): Neodvisno življenje invalidov $v$ izbranih državah evropske unije. Ljubljana, Inštitut Republike Slovenije za socialno varstvo.

Kobal, B., Dremelj, P., Nagode, M., in Smolej, S. (2006): Analiza trans- ferjev za invalide. Ljubljana, Inštitut Republike Slovenije za socialno varstvo.

Kobal, B. Dremelj, P., in Nagode, M. (2007): Analiza socialno ekonomskega položaja invalidov za pripravo Zakona o izenačevanju možnosti invalidov. Ljubljana, Inštitut Republike Slovenije za socialno varstvo.

Komisija Evropskih skupnosti (2000): Towards a barrier free Europe for people with disabilities. COM (2000) 284 final. Dostopno na: http://eur-lex.europa.eu/LexUriServ/LexUriServ. do?uri=com:2000:0284:fin:en:pdf (sneto 15. 4. 2009).

Komisija Evropskih skupnosti (2003): EU disability action plan. First phase 2004-2005. COM(2003) 650 final. Dostopno na: http:// ec.europa.eu/employment_social/news/2003/oct/en.pdf (sneto 15. 4. 2009).

Kervina, D., Pustinšek, M., in Bešter, J. (2007): Informacijske in komunikacijske tehnologije za e-vključenost. V: Hočevar, F. (ur.): Praktični vidiki in možnosti e-vključenosti in dostopnosti za invalide, starejše in za osebe z manjšimi možnostmi, str. 13-21. Ljubljana, Inštitut Republike Slovenije za rehabilitacijo.

Kresal, B. (ur.) (2007): Vodnik po pravicah invalidov v slovenski zakonodaji. Ljubljana, Inštitut za delo pri Pravni fakulteti.

Kukova, S., Zaviršek, D., in Urh, Š. (2005): Rights of people with intellectual disabilities. Access to education and employment: Slovenia (monitoring report). Budapest, New York, Open Society Institute.

McGrail, B., Percivel, J., in Foster, K. (2001): Integrated segregation? V: Peace, M. S., in Holland, C. (ur.): Inclusive housing in an ageing society. Innovative approaches, str. 147-168. Bristol, The Policy Press.

Milner, J., in Madigan, R. (2004): Regulation and innovation: Rethinking inclusive housing design. Housing Studies, 19(5), str. 727-744.

Ministrstvo za delo, družino in socialne zadeve (2006): Akcijski program za invalide 2007-2013. Dostopno na: http://www.mddsz. gov.si/fileadmin/mddsz.gov.si/pageuploads/dokumenti_pdf/ api_07_13.pdf (sneto 15. 4. 2009).

Nacionalne usmeritve za izboljšanje dostopnosti grajenega okolja, informacij in komunikacij za invalide. Uradni list RS št. 113/2005. Ljubljana.

Nagode, M., in Dremelj, P. (2005): Spolne razlike v omrežjih socialne opore za ljudi z gibalnimi težavami s Sloveniji. Socialno delo, 44(1-2), str. 117-123.

Nagode, M., in Dremelj, P. (2004): Omrežja socialne opore oseb z gibalnimi težavami. V: Novak, M. (ur.): Omrežja socialne opore prebivalstva Slovenije, str. 121-129. Ljubljana, Inštitut Republike Slovenije za socialno varstvo.

Ostrovršnik, B. (2004): Pametna hiša kot orodje in priložnost za lažjo komunikacijo ljudi z omejenimi sposobnostmi z različnimi okolji. V: Bešter, J., in Humar, I. (ur.): Pametne stavbe, str. 111-113. Ljubljana, Elektrotehniška zveza Slovenije.

Peace, M. S., in Holland, C. (ur.) (2001): Inclusive housing in an ageing society. Innovative approaches. Bristol, The Policy Press.

Pecora, F., in Cesta, A. (2007): DCOP for smart homes: A case study. Computational Inelligence, 23(4), str. 395-419.

Sandhu, J. S., Saarnio, I., in Wiman, R. (2001): Information and communication technologies and disability in developing counties. 
Dostopno na: http://siteresources.worldbank.org/DISABILITY/Resources/280658-1172609480904/InformationCommSandhu.pdf (sneto 14. 8. 2008).

Sendi, R., Černič Mali, B., Kerbler, B., Kobal, B., Smolej, S., Nagode, M., idr. (2008): Ukrepi za uresničevanje pravic invalidov do dostopa brez ovir. Ljubljana, Urbanistični inštitut Republike Slovenije.

Thomas, P. (2004): The experience of disabled people as customers in the owner occupation market. Housing Studies, 19(5), str. 781-794.

Ustavni zakon o spremembi 14. člena Ustave Republike Slovenije. Uradni list RS št. 69/2004. Ljubljana.

Vertot, P. (ur.) (2007): Invalidi in druge osebe s posebnimi potrebami v Sloveniji. Ljubljana, Statistični urad Republike Slovenije.

Vodeb, V. (2007): Diskriminacija zaradi nedostopno grajenega okolja: analiza nedostopnosti z metodami geomatike. Doktorska disertacija. Ljubljana, Univerza v Ljubljani, Fakulteta za arhitekturo.

Zupan, A., Cugelj, R., in Hočevar, F. (2007): Dom IRIS (Inteligentne rešitve in inovacije za samostojno življenje). Rehabilitacija, 6(1-2), str. 101-104. 